3. Shaw N, Hegedus G. The National Programme for Information Technology. The GP as a gatekeeper. A bastion with fighting for?. Br J Gen Pract 2005;55:85-6.

4. Starfield B. Research in general practice: comorbidity, referrals, and the roles of general practitioners and specialists. SEMERGEN 2003;29 (Supl):7-16.

5. Doorslaer E, Colman X, Puffer F. Equity in the use of physician visits in OECD countries has equal treatment for equal need been achieved?En: Measuring up: improving health system performance in OECD countries. Paris: OECD, 2002, pág. 222-48.

6. Rodríguez M, Stoyanova A. The effect of private insurance access on the choice of $\mathrm{GP} /$ specialist and public/private provider in Spain. Health Econ 2004;13:698-703.

7. Gérvas J, Pérez Fernández M. Aventuras y desventuras de los navegantes solitarios en el Mar de la Incertidumbre. Aten Primaria 2005;35:87-90.
8. Gérvas J. Oportunidades clínicas para compensar el impacto de las diferencias sociales en salud. Salud2000 2004;98:9-12.

9. Pérez Fernández M, Gérvas J. Encarnizamiento diagnóstico y terapéutico con las mujeres. SEMERGEN 1999;25:239-48.

10. Seguí M, Gérvas J. El dolor lumbar. SEMERGEN2002;28:21-41.

11. Master S, Longtreth GF, Liu AL. Results of computed tomography in family practitioners' patients with non-acute abdominal pain. Fam Pract 2005;22:474-7.

12. Gérvas J. Cuidados primários de saúde na Europa: tendencias atuais. Rev Bras Epidemiol 2004;7(3):350-69.

13. Lindley KJ, Glaser D, Mills PJ. Consumerism in healthcare can be detrimental to child health: lessons from children. Arch Dis Child 2005;90:335-7.

\title{
Primary Care: the Filter
}

Gervas and Perez-Fernandez ${ }^{1}$ provided the scientific rationale for the primary care physician as the "filter" in the medical care system. In their paper, they review the evidence that the functions of the primary care physician reduce unnecessary consultations with specialists, thus reducing the burden on specialists and releasing their time to deal with patients who can best benefit from their services.

In his commentary on the Gervas/ Perez-Fernandez paper, Campos ${ }^{2}$ argues against the filter on the grounds that it does not allow for responsiveness to demand. In fact, it is one of the purposes of the filter to respond to needs rather than to demands. In health care, "demand" has been responsible for great variability in the receipt of health services because the most socially advantaged are in a better position to express demands than are the social disadvantaged, thus leading to the inverse care law. The studies of Van Doorslaer and colleagues $^{3}$ have shown that almost all
OECD countries have eliminated inequities in use of primary care services, but few have eliminated inequities in receipt of specialty care, even those countries in which primary care serves as the point of first contact ("the filter"). Although equity of access for people who need specialty care is an appropriate goal, responsiveness to demand is not an appropriate goal.

An unanticipated result of responsiveness to demand for specialty care is the danger of adverse effects from unnecessary and excessive interventions, particularly when they are administered to people with low likelihood of benefit. In medical care, more is not necessarily better; it is often worse. A variety of studies show that there is no advantage to expanding the supply of specialists in areas already well supplied. ${ }^{4}$ Counties within the US, already oversupplied with many types of specialists, are also prone to fragmented care, manifested as a result of people seeing many physicians with consequent lack of 
coordination of services and greater rates of adverse effects. ${ }^{5}$ In the US, an increasing supply of neonatologists has not reduced neonatal mortality; in fact it is increasing as it is in Pelotas, Brazil, concomitant with increased Caesarean section rates. ${ }^{6,7}$ An adequate but not excessive supply of obstetric and neonatal services would not lead to such a situation.

It is unfortunate that the concept of a "filter" has become confused with the concept of the "gatekeeper". A filter is not the same as a gate, as the former is designed to select for characteristics that benefit from passage whereas the latter does not. In particular, a filter selects for those characteristics with a high probability of benefiting from passage. (Consider the case of filtering in the art of cooking!) A gate may be opened or closed arbitrarily, oftentimes with pressure, and sometimes depending on factors not related to need or benefit. Gates can be opened or closed to varying degrees by the gatekeeper, depending on their characteristics and the area in which they are located as well as on the degree of demand for entrance.

The basis for the adverse effects of an excessive use of specialists is directly related to the function of the filter. The utility of specialist interventions depends on raising the prevalence, within specialty practice, of people with a high likelihood of pathology requiring specialty care. By virtue of their training in specialty clinics in medical universities, specialty residents are exposed to people with a high likelihood of such problems and become accustomed to expecting the same in their subsequent work in community practice. As Gervas and Perez-Fernandez ${ }^{1}$ point out, in the absence of the filter, specialists are confronted with a high proportion of people with low likelihood of problems in their area of special competence. Hence, they carry out a cascade of increasingly invasive procedures and treatments, each with its potential for causing ill effects and even death. ${ }^{8}$ More specialists seeing patients with low likelihood of illness may do more harm than good, a phenomenon that may be related to high rates of death from adverse effects in overspecialized health systems such as the US. ${ }^{9}$

Now that much is known about the functions of primary care and its achievements in improving health and equity in health, ${ }^{10}$ it is time to turn attention to understanding the appropriate functions of specialty care. In the past half-century, great strides in developing highly technologic approaches to avoiding death and disability have been responsible for easing and even remedying discomfort, handicaps, and dysfunctions. (Examples are interventions restoring hearing in patients with hereditary otosclerosis, and restoring mobility in people with hip fractures.) But there is no scientific basis for estimating the number of specialists of various types required to meet population needs for the type of interventions that confer benefit. It is virtually certain that the proper function of the filter could release more time for appropriately deployed specialists to deliver the services that would greatly improve health and, especially, equity in health.

Recognition of the importance of the first contact function in primary care should lead us to concerted study of this important aspect of health professional supply, considering needs of populations for specialist care rather than demands for it. Based on evidence from such studies, the design of the filter should be set to maximize the effectiveness of primary care and specialty services, just as manufacturers set filters to achieve specific purposes.

Barbara Starfield, MD, MPH University Distinguished Professor Johns Hopkins University \& Medical Institutions

624 North Broadway, Room 452 Baltimore, Maryland 21205

Phone 410-955-3737

Fax 410-614-9046 bstarfie@jhsph.edu 


\section{Reference List}

1. Gervas J, Perez Fernandez M. [The scientific basis for the gatekeeping role of general practitioners]. Rev Bras Epidemiol 2005; 8(2):105-218.

2. Campos GWS. [Filter function razor edge: thinking about clinical function on Unique Health System in Brazil]. Rev Bras Epidemiol 2005; 8(4):477-483.

3. van Doorslaer E, Masseria C, Koolman X. Inequalities in access to medical care by income in developed countries. Can Med Assoc 2006; 174(2):177-183.

4. Starfield B, Shi L, Grover A, Macinko J. The effects of specialist supply on populations' health: assessing the evidence. Health Aff 2005; W5:97-107 (also available at http:// content.healthaffairs.org/cgi/reprint/ hlthaff.w5.97v1)

5. Schoen C, Osborn R, Huynh PT, Doty M, Zapert K, Peugh J, et al. Taking the pulse of health care systems: experiences of patients with health problems in six countries. Health Aff 2005; W5:509-525 (also available at http://content.healthaffairs.org/cgi/reprint/ hlthaff.w5.509v3)
6. MacDorman MF, Martin JA, Mathews TJ, Hoyert DL, Ventura SJ. Explaining the 20012002 infant mortality increase in the United States: data from the linked birth/infant death data set. Int J Health Serv 2005; 35(3):415-442.

7. Barros FC, Victora CG, Barros AJ, Santos IS, Albernaz E, Matijasevich A, et al. The challenge of reducing neonatal mortality in middle-income countries: findings from three Brazilian birth cohorts in 1982, 1993, and 2004. Lancet 2005; 365(9462):847-854.

8. Graboys TB. The economics of screening joggers. N Engl J Med 1979; 301(19):1067.

9. Starfield B. Is US health really the best in the world? JAMA 2000; 284(4):483-485.

10. Starfield B, Shi L, Macinko J. Contribution of primary care to health systems and health. Milbank Q 2005; 83(3):457-502. 